\title{
How to Squeeze Expensive Pastries: Five Performances by Diane Borsato
}

\section{Diane Borsato}

Dans cette cuvre, Diane Borsato présente des images et des réflexions personnelles portant sur plusieurs projets récents de représentation ayant lieu à la maison et dans la ville. Parmi ceux-ci, Sleeping with Cake, où l'artiste a dormi avec des aliments-doudous, afin de voir si ça la réconforterait; The Taste of Love Awards, où elle offre des certificats de mérite aux restaurants qui servent de la nourriture contenant un " petit goût d'amour " insaisissable; et How to Squeeze Expensive Pastries, une démonstration faite avec des écoliers dans une intersection bondée à TaiChung, en Taïwan.

\section{Sleeping with Cake}

I was reading about Marina Abromovic and her work with crystals. Between camping out in crystal mines and setting up installations to stare at different crystals, she also slept with them, hoping to absorb the benefits of their unique powers. I wondered about the powers of more familiar everyday objects. In the spirit of my recent investigations into sources of

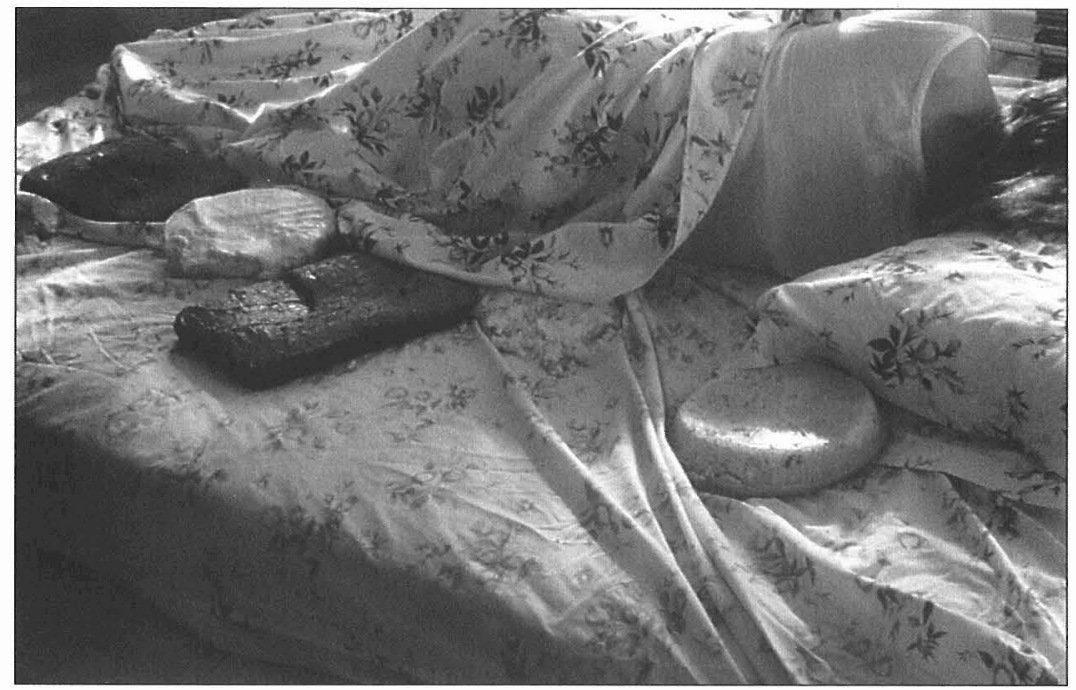

Sleeping with Cake, by Diane Borsato, Montreal, 1999 Photo: Diane Borsato 
love, and comfort, it seemed obvious to me that I should sleep with comfort food. I baked and bought cakes with a unique agenda. After too many nights sleeping alone, I wondered if their presence with me in bed would provide company and comfort me. Would sleeping with comfort food be comforting? How will that chocolate cream roll feel against my body? Can the comfort in comfort-food be accessed in this way? I appraised the cakes as bed partners, appreciating the shape and firmness and weight of them. I wondered if I could absorb particular qualities of cake into my body - not by eating it - but by taking it to bed like a lover.

Enacting this eccentric experiment resulted in a few observations. There were cakes all around me with my long red hairs stuck in their cream, and there were chunks and crumbs of cake all over the bed, and the floor. Around me were various chocolate cakes, vanilla and cherry cakes, a marble cake, a lemon cake, and a flan. I expected the stickiness and crumbs it seems such discomforts are always a consequence of intimate company - but I was genuinely shocked to have slept so well. I actually could appreciate the weight of the cakes around me. They felt like bodies, like a bed full of sleeping cats. I was not sleeping alone. In the morning I lingered in bed for a while amongst the cake rubble, thinking about the power of food less in terms of taste than as a physical presence - as a thing in your hands and mouth, as a weight in your belly, and as company beside you.

\section{The Broth}

When I boiled A Natural History of the Senses by Diane Ackerman, it seemed ironic that such a pleasant book could produce such offensive toxic fumes. I used boiling as another way to access the meaning of a book - the way we might boil a chicken to distill all its value. I was so sad when I put it in the pot. I looked at my name written in the corner of the first page with 1993 written next to it under the water. For this project, The Broth, I've boiled various sentimental objects: my worn, old copy of my favourite book, my precious steel toe boots, and several love letters. I felt at once like a scientist enacting an experiment, like a forensic investigator gathering evidence, like the perfumer in the Patrick Suskind novel Perfume who tries to distill the very essence of love. I didn't know if my broth would be comforting, or contain the essence of sentiment, or how in fact I would absorb any available comfort into my body. I threw the mangled boiled objects away, and was left only with my 'broth' - still wondering about the difference between the sentiment and the object - the location of comfort or nostalgia - and whether it's ever possible to separate the essence from the physical reality of the thing. 


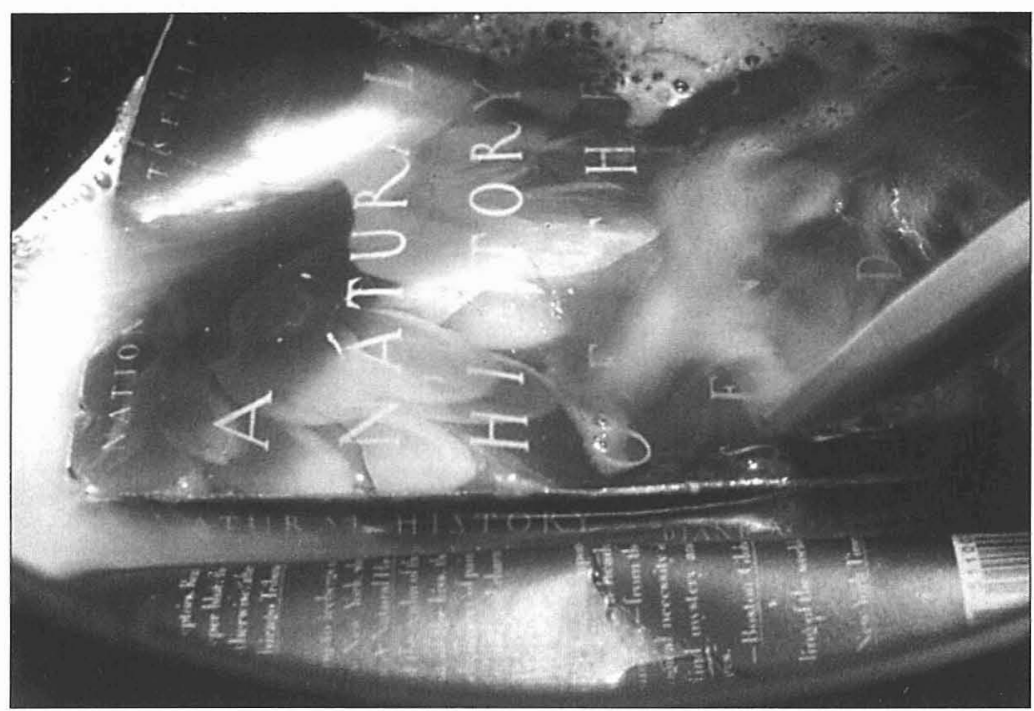

The Broth, by Diane Borsato, Montreal, 1999 Photo: Diane Borsato

\section{The Taste of Love Awards}

I was interested in acting like a food reviewer, and sampling meals in restaurants to describe their quality and measure their value. I was interested in an alternative approach, and a means to acknowledge love as an ingredient in food, an experience of food, and as an essential nutrient.

When I first lived alone, I recognized that when food is rarely served to you because anyone actually cares about you, and you exchange money for every last condiment and crumb - you run a serious risk of Food-Love deficiency. I wanted to describe this elusive experience of love in food, so I created a broad definition of The Taste of Love - which included food that was not only good, but food that was good and had Love in it according to my own unique experience, culture and tastes. I developed a definition of The Taste of Love - where it resembles the touch of a loved one more than a taste at all, and also a set of criteria to measure restaurant experiences by. Some of the Factors which affect The Taste of Love according to my criteria included: When Food is Cooked by Someone who Loves You, Eating with Someone you Love, Romantic Ambience, Warm Service, When Ingredients have been Handled with Affection, The Right Ingredients, The Taste of Nostalgia, and, When Your Heart Insists. In order to recognize these characteristics, and characterize love as an under-appre- 


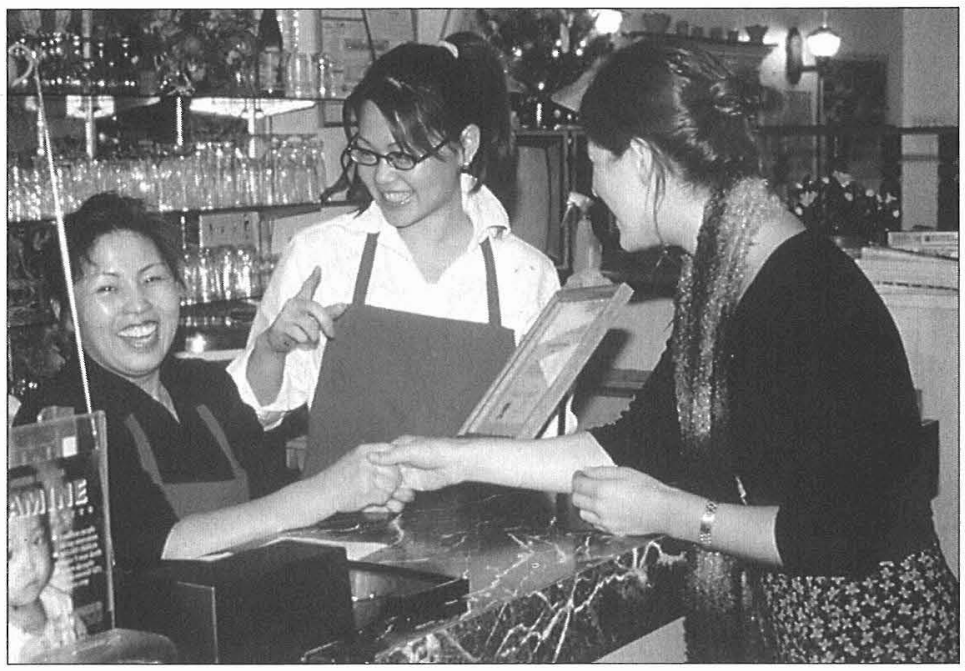

The Taste of Love Awards / Recognizing the Taste of Love, by Diane Borsato, Montreal, 1999-2000. Photo: Dean Baldwin

ciated 7th essential nutrient, I presented several outstanding examples of restaurants with The Taste of Love Award. I made formal presentations of the framed Award with a photographer taking pictures. I tried to make it clear to the restaurant owners that I was an artist and that I wanted to recognize, encourage and thank them for the special touches they have invested in their businesses. They all have since hung the awards, and I hope that any customers who might notice them may have a more aware, improved experience of their food.

\section{The Holding Performance}

Bread has a long history, and a great significance in various dimensions of our lives. It is a metaphor for basic nourishment; it punctuates holidays, religious rituals, and marks our memories of home and everyday life. Of special interest to me, however, was exploring a particular relationship of bread to the body, and exploring it as a body itself. From this point of departure I created The Holding Performance.

In this gesture, I made a large batch of yeasty bread dough, and held it in my lap for approximately 2 hours, waiting for it to rise. In this, I was hoping to experience intimately the magic of yeast going through its natural process, to hold in my arms the slow intake of breath, the imperceptible expansion, an experience of bread as a living thing. Also, I was interested in the rising process as a way to frame, or hold a period of time. 


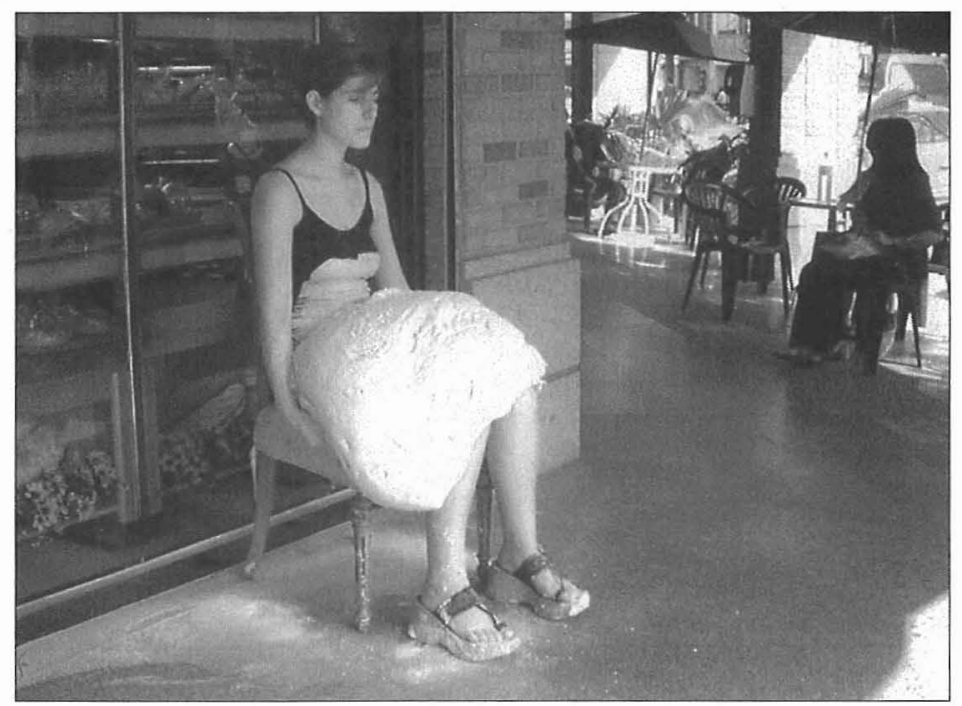

The Holding Performance, by Diane Borsato, Mystore Bakery, Taichung City, Taiwan, 2001. Photo: ManRay Hsu

The piece would be a kind of meditation, supported by the experience of a material in time. And the gesture of holding, referring both to a pause and to an intimate embrace.

The experience of the activity had several surprises, and as a meditation it provided the space and time for reflection inside it. I felt the dough swallow my arms and slide heavily down my legs. A mushy glacier. A slow avalanche. A flesh blanket. A sleeping child. The dough and I had a balanced relationship at first, each warming the other, supporter and comforter, two breathing beings. Spectators gathered for long periods on the busy Taiwanese street, and it felt extraordinary to me that people were stopping for long periods to watch the bread rise - watching bread rise could be a spectacle! Holding became a means for me to present and frame a basic, almost invisible process out for contemplation.

\section{How to Squeeze Expensive Pastries}

In How to Squeeze Expensive Pastries I was continuing my efforts to explore various experiences of comfort food. I was interested in exploring our relationship to the gooey, crumbly, sensuous - even bodily - physicality of decadent sweets. The taste of sweets are an obvious pleasure, but a large part of the experience of this kind of food extends beyond taste. Of course we want to eat pastries, but our relationship to them is larger. There is an 
urge to hold and treasure a beautiful pastry, a sense of admiration for its aesthetic qualities, and there are mixed feelings of love and hate for these rich, fattening objects, especially from women. I wanted to squeeze food -

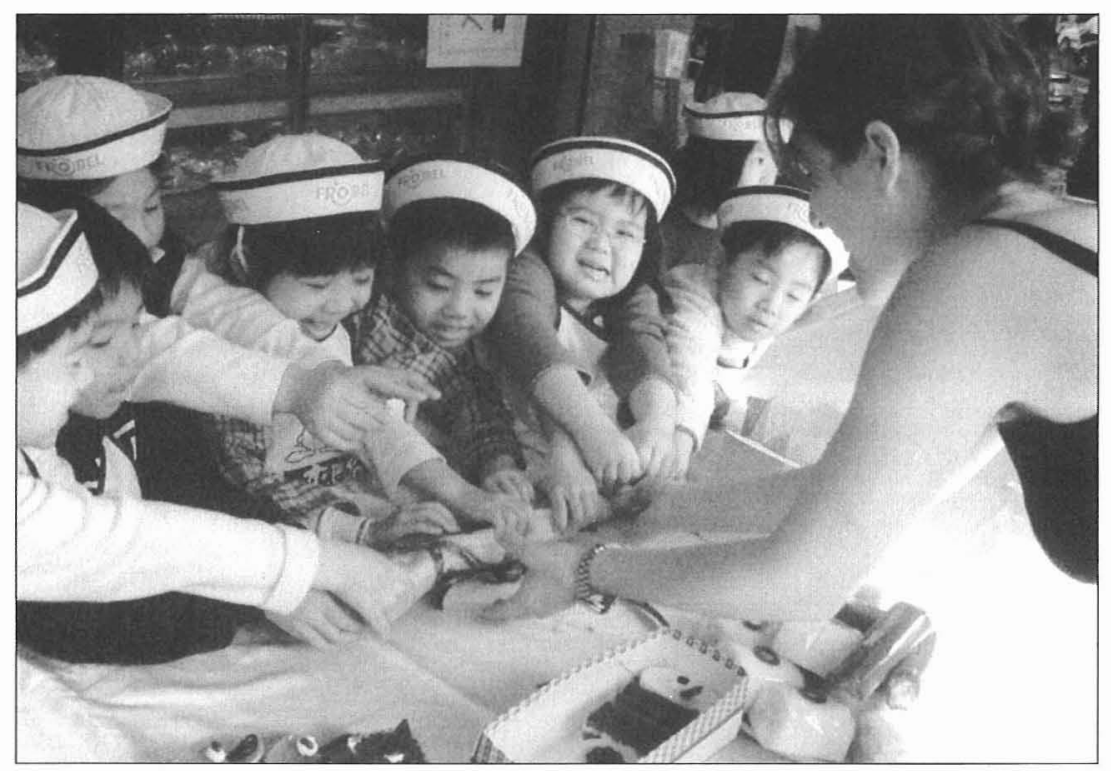

How to Squeeze Expensive Pastries, by Diane Borsato, Taichung City, Taiwan, 2001. Photo: ManRay Hsu

to indulge in an urgent and passionate act - as a way to both gorge on the physicality of food and to express various associations, emotions and weaknesses. I decided to include a group of young children in my performance, as children seem to connect easily to the humour, power, and thrill of cream gushing out from between their fingers, and in watching contained shapes collapse and explode. 